\title{
Measurement of Seed Viability with the Help of Electrical Conductivity Method
}

\author{
Arvind Kumar $^{1}$ and Avadhesh Kumar Koshal ${ }^{2 *}$ \\ ${ }^{1}$ Assistant Professor, Faculty of Agriculture, Motherhood University, Roorkee, India \\ Haridwar, UK \\ ${ }^{2}$ Professor, Faculty of Science, Motherhood University, Roorkee, India Haridwar, UK \\ *Corresponding Author: Avadhesh Kumar Koshal, Professor, Faculty of Science, \\ Motherhood University, Roorkee, India Haridwar, UK.
}

Received: December 21, 2021

Published: January 28, 2022

(C) All rights are reserved by Arvind Kumar and Avadhesh Kumar Koshal.

\begin{abstract}
Freshly harvested seeds of three genotype of Brinjal were collected from the Meerut District (U.P.) to determine relationship between the viability of seeds and the electrical conductivity of seeds. Seeds were divided into 3 genotypes of Brinjal seeds. Viability of Brinjal seed was found to be critically influenced by Electrical Conductivity of freshly harvested seeds at different level of Electrical Conductivity. The present result there by confirms the recalcitrant nature of Brinjal seeds step in the retention of Brinjal seed viability. As such, if the initial seed Electrical Conductivity is high, germination may take place during storage itself, and if too low, the final seed Electrical Conductivity in a particular treatment may fall below the desirable Electrical Conductivity range resulting in the higher viability. Result shows that Bio-Black Beauty genotypes having highest viability of Brinjal seeds and moderate value of viability is shown by Utkarsha and lowest shown by Bhima Brinjal seeds.
\end{abstract}

Keywords: Electrical Conductivity; Genotype; Salinity and Viability

\section{Introduction}

Seed vigour is an important quality parameter which needs to be assessed to supplement germination and viability tests to gain insight into the performance of a seed lot in the field or in storage. Several definitions have been offered to explain seed vigour. Looking into the complexity of the situation. The ISTA congress in 1977 adopted the definition of seed vigour as "the sum total of those properties of the seed which determine the level of activity and performance of the seed or seed lot during germination and seedling emergence".

The conductivity measurement was conducted according to recommendations by the International Seed Testing Association [1]. Seed vigour is an important component of seed quality and satisfactory levels are necessary in addition to traditional quality criteria of moisture, purity, germination and seed health to obtain optimum plant stand and high production of crops. As agricultural and horticultural techniques become progressively more sophisticated, the need for high vigour seeds will increase and testing standards, similar to those recognized for germination will be required [2]. It [3] used electrical conductivity as an indicator of seed viability and presents two advantages: to provide rapid and reliable results and the technique is not destructive and can use the seeds after the conductivity test, so they can be used to produce seedlings. The present study showed that different soaking times had no effect on the results of conductivity testing of freshly collected $K$. coriacea Mart. seeds, suggesting that the amount of leached matter was never below the threshold required for adequate testing. Seed germination is crucial stage in plant development and can be considered as a determinant for plant productivity. Physiological and biochemical changes followed by morphological changes during germination are strongly related to seedling survival rate and vegetative growth which consequently affect yield and quality [4]. 
In the early years of the twentieth century, as a result of the beginning of agricultural research a few improved strains of brinjal, wheat, groundnut and sugarcane came into existence. The state department of agricultural are adopted two methods for the distribution of seeds of the improved varieties, in the first method "Howard, 1928" [5]. The seeds of improved varieties were multiplied at one location and distribution over a largest area so that the area under local varieties could be replaced by improved varieties. By the second method the seeds were distributed in small packets to a maximum number of farmers, and it was expected that farmers would multiply their own seed. However, when the second method was tried in Bengal by distributing packets of jute and brinjal seeds, it was found that this did not increase the spread or coverage under new strains. As a result, this practice was discontinued and attention was concentrated only on the first method.

In the United Provinces (U.P.) the responsibility for replacing old varieties was placed on the State Department of Agricultural. Several seed multiplication laboratories were set up in the State to achieve these goals. The seed multiplied at these laboratories were further multiplied on the farms of landlords. This marked the beginning of the distribution of good quality seed. To encourage the use of good quality seed further, provisions for liberal loans were also made. Loans were granted for the purchase of good seed particularly during crop failures due to natural disaster. With these developments, the Government of the United Provinces in 1922 agreed to establish one seed store in each tehsil. Since then, the State Department of Agricultural has been steadily increasing the number of seed stores. Seed viability denotes the degree to which a seed is alive, metabolically active, processing germination power and seeding growth. A seed may contain both live and dead portion. The testa of higher plant seeds protects the embryo against adverse environmental conditions. Its role is assumed mainly by controlling germination through dormancy imposition and by limiting the detrimental activity of physical and biological agents during seed [6]. A practical index of salinity is electrical conductivity (EC), expressed in unit of milli siemen. An approximate relation (because it also depends upon specific ionic composition) between Electrical Conductivity and total salt concentration is $\mathrm{lds} / \mathrm{m}$ : $10 \mathrm{mmol}$. Electrical conductivity values are always expressed at a standard temperature of $25^{\circ} \mathrm{C}$ to enable comparison of reading taken under varying climatic conditions. Using electrical conductivity as an index of Salinity emphasizes the concept that as a good first approximation, seeds respond primarily to total concentration of salt rather than to the concentrations or proportion of individual salt constituents. The Electrical Conductivity (EC) of most water sources was below 0.7 milli siemen which does not pose a salinity problem however some drain water sources, may contribute to seed salinity problem. Field water and seed Electrical Conductivity level increased significantly from sample to sample. (Bio-Black Beauty to Bhima). Brinjal yield decreased with increased Electrical Conductivity and were significantly lower in sample basins compared to basins. Seedling density biomass decreased with increased water Electrical Conductivity. In general, the sequence noted in sulphate-Brinjal water near the surface, saline bicarbonate water at an intermediary level and more concentrated chlorides water at greater depths [7].

It investigates the relationship between seed germination and electrical conductivity [8].

That seeding seedling establishment and growth were greatly affected' This was observed in several higher Electrical Conductivity samples. Most of the problem of samples were associated with higher Electrical Conductivity drain water sources. [9], Observed that different parts of the seed absorb X-rays in different degrees. Solutions of metallic salts used in X-rays are absorbed by dead cells and these cannot penetrate into living cells because of their semi permeability. Main advantage of this test is that the seed used in testing (X-rayed) can be used for X-rays testing of seeds. The following objectives were measurement of brinjal seed viability with the help of electrical conductivity method.

There is describe a biotic stress is a major environmental stress impeding crop productivity throughout the world [10]. Brinjal yield are lost each year due to various abiotic stresses such as alkalinity and drought. Various genes are induced by abiotic stresses and contribute to overcoming adverse effects. It [11] showed this experiments that electrical conductivity test method with $150 \mathrm{ml}$ water volume and 75 seed count was accurate and suitable for sorghum seed vigor test; electrical conductivity test showed positive correlation with potassium leakage; and electrical conductivity test can be used for seed vigor test in sorghum and provided the potential of physiological seed were shown through: standard germination test, field emergence test, first count test and speed of germination with negative correlation.

\section{Materials and Methods}

Freshly harvested seeds of three genotype of Brinjal were collected from the Meerut District (U.P.) to determine relationship be- 
tween the viability of seeds and the electrical conductivity of seeds, seeds were soaked in distilled water at a temperature rf (301 - 1) ${ }^{\circ} \mathrm{C}$ in 2:1 Ratio (Distilled Water. and Seeds) in the $250 \mathrm{ml}$ beakers. Seeds were divided into 3 genotype of Brinjal seeds. Each sample was taken at 24, 48, and 72 hours three determining Electrical Conductivity from each sample Electrical Conductivity meter was used for determining Electrical Conductivity and the different reading were obtained.

\section{Calibration of electrical conductivity meter}

Electrical Conductivity meter was ser at the definite Electrical Conductivity in 1407 milli siemen units. For this process the Electrical Conductivity of a standard potassium Chloride (KCL) solution having $0.02 \mathrm{M}$, Molarity at the same temperature $25^{\circ} \mathrm{C}$ is also set and solution having different Brinjal genotypes the Electrical Conductivity was measured of every sample.

Viability in Brinjal seeds soaked in distilled water is characterized as the total content of the dissolved organic and inorganic solute. It is conventionally determined by measuring the electrical conductivity. The electrical conductivity is a measurement of the ability of a salt solution to carry electric current by the migration of ions under the influence of an electric field ions are the carrier of electricity. Like metallic conductor, solutions also obey Ohm's law. Increase in temperature also promotes dissociations of the salts with a consequent rise in temperature promotes dissociation of the salts with a consequent rise in conductivity at the rate of approximately $2 \%$ for each degree Celsius rise in temperature [12]. At infinite dilution, the ions are theoretically independent of each other, and each ion has its contribution to the total conductance.

Thus,

$\lambda \alpha=\sum\left(\lambda^{+}\right)+\sum(\lambda)$

Where,), $\lambda \alpha$ is the total conductance,

$\sum\left(\lambda^{+}\right)$Is the conductance of cations and

$\Sigma(\lambda)$ Is the conductance of anions at infinite dilution.

The test solution is filled in a conductivity cell, which is usually made out from two platinum sheets embedded in glass so that the two surfaces facing each other remain exposed. The area and distance between these plates must remain constant. The cell constant, $\mathrm{K}$, of a conductivity cell is determined by measuring the electrical conductance of a standard KCL solution at the same temperature according to the equation.
$\mathrm{K}=\frac{\mathrm{L}}{\mathrm{C}}$

Where, $\mathrm{L}$ and $\mathrm{C}$ are measured conductance of the cell is milli siemen. The known specific electrical conductance and the standard solution (usually $0.02 \mathrm{M} \mathrm{KCL}$ ) in the given cell is milli siemen.

\section{Results, Discussion and Conclusion}

Viability of Brinjal seed was found to be critically influenced by Electrical Conductivity of freshly harvested seeds at different level of Electrical Conductivity. But when the Electrical Conductivity of the seed dropped below 2 milli siemen viability started to increase and at 4.02 milli siemen seeds became virtually nonviable. Electrical Conductivity is an important factor of viability of seeds, because when Electrical Conductivity drops below a critical level seeds start to deteriorate but when the Electrical Conductivity exceeds a supra optimal level, viability decreases. The present results are in general conformity with Electrical Conductivity which plays an important role to determine the seed grow or viability, and also declined progressively with the loss of seed nutrient.

The present result there by confirms the recalcitrant nature of Brinjal seeds step in the retention of Brinjal seed viability. As such, if the initial seed Electrical Conductivity is high, germination may take place during storage itself, and if too low, the final seed Electrical Conductivity in a particular treatment may fall below the desirable Electrical Conductivity range resulting in the higher viability. The germ inability and subsequent growth of the cracked and sprouted seeds however as good as the none germinated viable seeds. From the present study it concluded that improved storability of Brinjal seed under ambient condition is possible by maintaining proper seed moisture content and controlling microbial spoilage. Result shows that Bio-Black Beauty genotypes having highest viability of Brinjal seeds and moderate value of viability is shown by Utkarsha and lowest shown by Bhima Brinjal seeds.

\begin{tabular}{|l|c|c|c|c|}
\hline \multirow{2}{*}{ S. No. } & \multirow{2}{*}{ Name of verities } & \multicolumn{3}{|c|}{ Electrical conductivity at } \\
& & $\mathbf{2 4 h r}$ & $\mathbf{4 8 h r}$ & $\mathbf{7 2 h r}$ \\
\cline { 3 - 5 } & & 1.9 & 2.13 & 2.21 \\
\hline 1 & Bio-Black Beauty & 1.55 & 1.69 & 1.75 \\
\hline 2 & Utkarsha & 1.48 & 1.63 & 1.72 \\
\hline 3 & Bhima &
\end{tabular}

Table 1: Electrical Conductivity of different variety of Brinjal seeds at different time intervals Decreasing order of Viability. Bio-Black Beauty $>$ Utkarsha $>$ Bhima. 


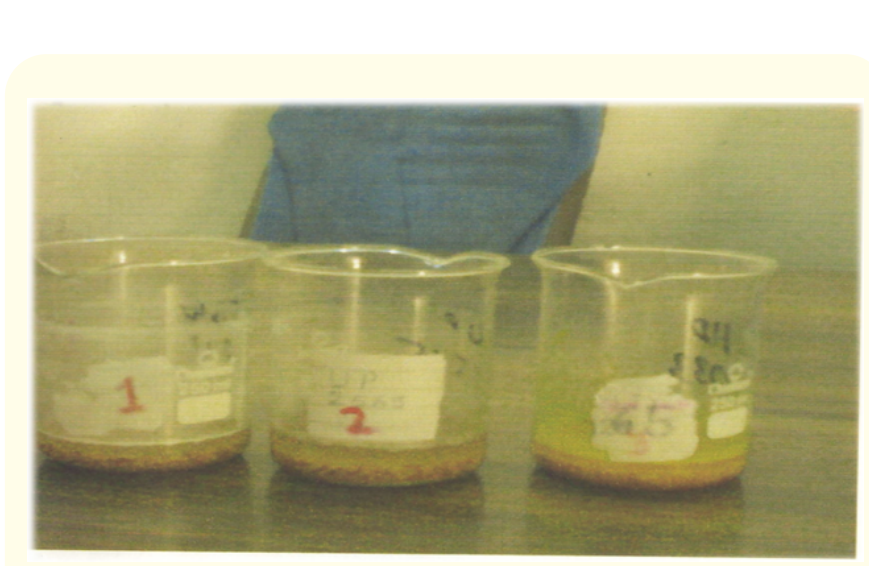

Figure 1: Brinjal seed sample.

1: Bhima, 2: Utkarsha, 3: Bio-Black Beauty.

\begin{tabular}{|c|c|c|c|}
\hline Water class & $\begin{array}{c}\text { Electrical } \\
\text { conductivity } \\
\text { mS/m }\end{array}$ & $\begin{array}{c}\text { Salt } \\
\text { concentration } \\
\mathrm{mg} / \mathbf{l}\end{array}$ & $\begin{array}{l}\text { Type of } \\
\text { water }\end{array}$ \\
\hline Non-saline & $<0.7$ & $<500$ & $\begin{array}{c}\text { Drinking and } \\
\text { irrigation } \\
\text { water }\end{array}$ \\
\hline Slightly saline & $0.7-2$ & $500-1500$ & $\begin{array}{c}\text { Irrigation } \\
\text { water }\end{array}$ \\
\hline $\begin{array}{l}\text { Moderately } \\
\text { saline }\end{array}$ & $2-10$ & $1500-7000$ & $\begin{array}{l}\text { Secondary } \\
\text { drainage } \\
\text { water and } \\
\text { groundwater }\end{array}$ \\
\hline Highly saline & $10-25$ & $7000-15000$ & $\begin{array}{l}\text { Very saline } \\
\text { groundwater }\end{array}$ \\
\hline $\begin{array}{l}\text { Very highly } \\
\text { saline }\end{array}$ & $25-45$ & $15000-35000$ & $\begin{array}{l}\text { Very saline } \\
\text { ground } \\
\text { water }\end{array}$ \\
\hline Brine & $>45$ & $>45000$ & Seawater \\
\hline
\end{tabular}

Table 2: According to FAO (1996) the following data were observed for good health of Maize seeds.

\begin{tabular}{|c|c|c|}
\hline Water quality variable & Concentration level & Effects \\
\hline Calcium Bicarbonate Ca (HCO3)2 & $>60$ ppm (> 3 meqil) & $\begin{array}{l}\text { Soil pH increases near water inlet and inflow areas, } \\
\text { causing zinc to phosphorus deficiency in silt and } \\
\text { loam soils. }\end{array}$ \\
\hline $\begin{array}{l}\text { Electrical Conductivity (EC) (After } \\
\text { lime deposition) }\end{array}$ & $>770 \mathrm{ppm}$ & $\begin{array}{l}\text { Causes high soil salinity which can injure or kill seed- } \\
\text { ing of Maize }\end{array}$ \\
\hline Chloride (Cl) & $>100 \mathrm{ppm}(>3 \mathrm{meq} / \mathrm{L})$ & $\begin{array}{c}\text { Contributes to measured EC level. (High Cl along may } \\
\text { pose a problem for Acidity). }\end{array}$ \\
\hline Sodium Adsorption Ration (SAR) & $>10$ & Causes sodic soil which has poor physical condition \\
\hline $\begin{array}{l}\text { Lower levels can cause injury in } \\
\text { some cases. } \\
\mathrm{SAR}=\mathrm{Na}(\mathrm{Ca}+\mathrm{Mg} / 2 \text {, where } \mathrm{Na}, \mathrm{Ca} \\
\text { and } \mathrm{Mg} \text { are in milli } \\
\text { equivalent liter). }\end{array}$ & & \\
\hline
\end{tabular}

Table 3: General Maize irrigation water quality Guide.

\section{Bibliography}

1. ISTA. "International Rules for Seed Testing". Seed Science and Technology (2003).

2. Perry DA. "Commentary on ISTA Vigour Test Committee Collaborative Trial". Seed Science and Technology 12 (1984): 301308.
3. Kennya Mara Oliveira Ramos., et al. "Electrical Conductivity Testing as Applied to the Assessment of Freshly Collected Kielmeyera coriacea Mart". Seeds. Int. Scholarly Research Notices: ISRN Agronomy (2012): 1.

4. Ali AS and Elozeiri AA. "Metabolic Processes During Seed Germination. Advances in Seed Biology. Edited by Jose Carlos Jimenez- Lopez". Spanish National Research Council (CSIC) (2017). 
5. Agarwal RL. "Seed Technology". Oxford and IBH Publishing Company Pvt. Limited (2018): 848.

6. Debeaujon I., et al. "Influence of the Testa on Seed Dormancy, Germination, and Longevity in Arabidopsis". Plant Physiology 122 (2 (2001): 403-414.

7. Craig JR. "Saline waters: genesis and relationship to sediments and host rocks". In: Saline Water Proc. Symp. Groundwater Salinity, $46^{\text {th }}$ Annual meeting. R.B. Mattox (ed.). American Association for the Advancement of Science (AAAS), Las Vegas, Nevada (1980).

8. Tiwari K and Rajput A. "Electrical conductivity as a measure of seed viability of seeds of Adina cordifolia, Mitragyna parvifolia and Hymenodictyon excelsum". Conference Proceedings: Biology (1996).

9. Anonymous. "International Rules for seed Tastings". Seed Science and Technology 13 (1985): 307-320.

10. Wang WB Vinocur and A Altman. "Plant responses to drought, salinity and extreme temperature: towards genetic engineering for stress tolerance". Planta 218 (2003): 1-14.

11. Fatonah K., et al. "Electrical conductivity for seed vigor test in sorghum (Sorghum bicolor)". Cell Biology and Development 1.1 (2017): 6-1.

12. Bower CA and Wilcox LV. "Soluble Salts, Methods of Soil Analysis". American Society of Agronomy, Madison (1965): 933-940.

\section{Assets from publication with us}

- Prompt Acknowledgement after receiving the article

- Thorough Double blinded peer review

- Rapid Publication

- Issue of Publication Certificate

- High visibility of your Published work

Website: www.actascientific.com/

Submit Article: www.actascientific.com/submission.php

Email us: editor@actascientific.com

Contact us: +919182824667

Citation: Arvind Kumar and Avadhesh Kumar Koshal. "Measurement of Seed Viability with the Help of Electrical Conductivity Method". Acta Scientific Agriculture 6.2 (2022): 59-63. 